\title{
Asas “No Work, No Pay” Terhadap Mogok Kerja Buruh Berdasarkan Undang-Undang Ketenagakerjaan
}

\author{
Sahur Ramsay \\ Fakultas Hukum, Universitas Muhammadiyah Sorong \\ Email : sahur_ramsay@yahoo.com
}

\begin{abstract}
Abstrak
Penelitian ini bertujuan untuk mengetahui, menganalisis dan menjelaskan mogok kerja sah yang berhak mendapatkan upah sesuai dengan asas no work, no pay. Dalam undang-undang ketenagakerjaan menjelaskan lebih rinci tentang mogok kerja yang berhak mendapatkan upah. Metode yang digunakan dalam penelitian ini yaitu penelitian normatif yuridis. Penelitian normatif atau studi kepustakaan, data yang diperoleh merupakan data sekunder. Data yang diperoleh kemudian dianalisi secara kualitatif dan disampaikan secara deskriptif. Asas No Work, No Pay sangat erat kaitannya dengan pengupahan. Pemberian upah integral dengan ide, gagasan dan tenaga yang dioptimalkan buruh/pekerja. Asas No Work, No Pay tetap dipertahankan semenjak diberlakukannya KUHPerdata sebagai peraturan yang mengatur ketenagakerjaan sampai sebagian pasal dalam KUHPerdata tidak berlaku semenjak di sahkannya Undang-Undang Ketenagakerjaan. Dalam UUK asas no work, no pay terdapat pengecualian, buruh masih memperoleh upah apabila, tidak bekerjanya tersebut tergolong yang diatur dalam pasal 93 ayat 2 UUK. Mogok kerja sah yang dilakukan oleh pekerja/buruh mendapatkan perlindungan dari Negara, sehingga pemberi kerja diwajibkan membayarkan upah selama melakukan mogok kerja. UUK lebih rinci perilah pemberian upah pekerja/buruh yang mogok kerja. Yaitu hanya mogok kerja sah dan tuntutannya hak normatif yang betul-betul dilanggar oleh pemberi kerja yang berhak mendapatkan upah.
\end{abstract}

Kata Kunci : Asas No Work, No Pay, Mogok Kerja, Dan Upah.

\section{PENDAHULUAN}

Pekerjaan merupakan bagian yang tidak dapat dipisahkan dalam kehidupan setiap orang, disebabkan setiap orang membutuhkan pekerjaan tidak hanya untuk memperoleh penghasilan guna memenuhi kebutuhan hidup bagi diri dan keluarganya tetapi juga sebagai pembuktian atau eksistensi dirinya dalam lingkungan masyarakatnya sehingga merasa hidupnya menjadi lebih bermakna bagi diri sendiri, orang lain dan lingkungannya.

Pentingnya pekerjaan bagi setiap orang di insyafi para pendiri bangsa dengan dituangkan dalam konstitusi. Pasal 27 ayat 2 (dua) Undang-Undang Dasar Negara Republik Indonesia 1945, yang selanjutnya ditulis UUD 1945, menyatakan : Tiap-tiap warga berhak atas pekerjaan dan penghidupan yang layak bagi kemanusiaan. Dalam Pasal 28D ayat 2 (dua) UUD 1945: Setiap orang berhak untuk berkerja dan mendapatkan imbalan dan perlakuan yang adil dan layak dalam hubungan kerja. Pengakuan dari Negara bahwa pekerjaan merupakan hak, 
maka berimplikasi kewajiban bagi negara untuk memfasilitasi atau menyediakan lapangan pekerjaan bagi warga negaranya.

Hubungan kerja pada dasarnya adalah hubungan antara buruh/pekerja dan majikan/pemberi kerja setelah adanya perjanjian kerja, yaitu suatu perjanjian di mana pihak kesatu, si buruh mengikatkan dirinya pada pihak lain, si majikan untuk bekerja dengan mendapatkan upah; dan majikan menyatakan kesanggupannya untuk mempekerjakan si buruh dengan membayar upah. Perjanjian kerja merupakan payung hukum yang menaungi antara pekerja/buruh dengan pemberikerja atau pengusaha untuk melakukan suatu pekerjaan. Pekerjaan tersebut merupakan perintah dari pengusaha yang nantinya akan mendapat imbalan atau kontra prestasi dari pekerjaan yang dilakukan. Besarnya upah yang diperoleh pekerja sesuai dengan perjanjian yang disepakati oleh kedua belah pihak.

Konsepsi pekerja/buruh dalam KUHPerdata diibaratkan sebagai "barang” Pasal 1602b KUHPerdata "Tidak ada upah yang harus dibayarkan untuk jangka waktu selama si buruh tidak melaksanakan pekerjaannya”. KUHPerdata yang mengatur tentang perburuhan bersifat liberal tidak sesuai dengan kepribadian bangsa Indonesia yang berlandaskan pancasila dengan nilainilai gotong royong.

Undang-undang Nomor 13 Tahun 2013 tentang Ketenagakerjaan, selanjutnya ditulis UUK, mengatur lebih lanjut tentang pekerja/buruh yang tidak bekerja masih memperoleh upah apabila mengalami hal-hal yang dicantumkan dalam Pasal 93 ayat 2 UUK. Pekerja/buruh dalam UUK tidak dianggap sebagai "benda" akan tetapi lebih dianggap sebagai mitra dalam bekerja. Pekerja di satu pihak dan manajemen atau pengusaha di pihak lain saling membutuhkan (mutual) satu sama lain. Pihak manajemen memerlukan kontribusi ide, gagasan, tenaga pekerja/buruh untuk mencapai tujuannya (target produksi), sedangkan pekerja/buruh membutuhkan pendapatan untuk memberikan kesejahteraan bagi keluarganya.

Hubungan industrial antara pekerja/buruh dan pengusaha tidak selamanya terjalin dengan harmonis dan dinamis, tidak tertutup kemungkinan setiap saat hubungan itu akan diwarnai perselisihan. Pemeo menyatakan, perselisihan hubungan industrial senantiasa akan terjadi, sepanjangan masih ada pekerja/buruh dan pengusaha. Hal itu dipicu dari adanya perbedaan kepentingan antara pekerja/buruh dan pengusaha. Pekerja dalam bargaining position yang lemah diperlakukan dengan sewenang-wenang, upah pekerja bernilai asimetris dengan produktifitasnya, tenaga diperas tanpa penghargaan yang pantas.

Peristiwa perburuhan yang belakangan ini terjadi merupakan fenomena gunung es, yaitu persoalan pekerja yang terlihatnya hanya permukaannya saja namun faktanya akar masalahnya cukup banyak dan sangat rumit. Posisi yang tidak seimbang antara pengusaha atau pemberi 
kerja dengan pekerja/buruh membuka peluang besar untuk terjadinya perselisihan hubungan industrial. Tidak seimbangannya antara lapangan pekerjaan dengan pencari pekerjaan dijadikan "kunci" oleh pengusaha atau pemberi kerja untuk melakukan perbuatan yang bertentangan dengan peraturan perundang-undangan yang merugikan pihak pekerja/buruh, disisi lain pekerja/buruh dengan banyaknya pencari kerja dan kurangnya lapangan pekerjaan membuat pekerja/buruh tidak mempunyai cukup keberanian untuk menuntut hak normatifnya apabila dilanggar oleh pengusaha atau pemberi kerja.

Pekerja yang mempunyai keberanian untuk menuntut hak normatifnya. Pada umumnya menunjukkan bentuk-bentuk konflik yang mewakili usaha-usaha di pihak pekerja untuk mengubah kondisi yang dianggap tidak memuaskan mencakup tindakan-tindakan seperti pemogokan, bekerja lambat, larangan lembur dan bahkan hanya duduk-duduk di tempat kerja.

Undang-Undang Nomor 13 Tahun 2003 tentang Ketenagakerjaan mengakomodir kepentingan buruh/pekerja yang ingin melakukan aksi mogok kerja. Mogok kerja dilakukan apabila jalur damai telah ditempuh dan tidak mendapatkan kesepakatan bersama antara pengusaha atau pemberi kerja dengan buruh/pekerja atau pengusaha menolak untuk melakukan perundingan. Pelaksanaan mogok kerja harus dilakukan secara sah, tertib dan damai. UndangUndang Ketenagakerjaan memberikan legitimasi untuk melakukan aksi mogok kerja akan tetapi prosedur untuk melakukan mogok kerja yang sah menurut Undang-Undang sangat sulit. Undang-Undang Ketenagakerjaan secara gamblang menyebutkan bahwa mogok kerja merupakan hak setiap pekerja akan tetapi kewajiban-kewajiban yang diembankan kepada pekerja/buruh yang ingin melakukan aksi mogok sangat menyulitkan.

UUK mengakui keberadaan mogok kerja (strike), berarti negara mengakui eksistensi dari mogok kerja yang dilakukan oleh buruh/pekerja. Mogok kerja dilakukan untuk menuntuk hak normative (hak yang diberikan oleh undang-undang) yang dilanggar oleh pengusaha/pemberi kerja. Mogok kerja merupakan "senjata" buruh untuk menyeimbangkan kedudukan antara buruh dan pengusaha. Mogok kerja yang diakui keberadaannya dalam UUK, akan tetapi tidak secara eksplisit dituangkan dalam pasal 93 ayat 2 UUK mengenai pengecualian dari asas ,No Work, No Pay,

Berdasarkan uraian latar belakang penulis mengambil rumusan masalah yaitu Bagaimana Keberadaan Asas “No Work, No Pay” Terhadap Aksi Mogok Kerja Buruh Di Indonesia.

\section{PEMBAHASAN}

Keberadaan Asas “No Work, No Pay” Terhadap Aksi Mogok Kerja Buruh Di Indonesia. 


\section{Eksistensi Asas No Work, No Pay dalam Hukum Ketenagakerjaan}

Kebijakan di bidang ketenagakerjaan, khususnya mengenai pengupahan erat kaitannya dengan masalah perlindungan bagi pekerja atau buruh. Salah satu item yang harus ada dalam hubungan kerja yaitu upah. Upah adalah hak pekerja/buruh yang diterima dan dinyatakan dalam bentuk uang sebagai imbalan dari pengusaha atau pemberi kerja kepada pekerja/buruh yang ditetapkan dan dibayarkan menurut suatu perjanjian kerja, kesepakatan atau peraturan perundang-undangan, termaksud tunjangan bagi pekerja/buruh dan kekuasaannya atas suatu pekerjaan dan/atau jasa yang telah atau akan dilakukan.

Kebijakan pengupahan mendapat perhatian yang utama, sebelum berlakunya undangundang kecelakaan kerja. Masih menggunakan KUHperdata pengupahan didasarkan pada perjanjian antara pemberi kerja dan pekerja atau buruh. Pasal 1602 KUHPerdata menyatakan, majikan diwajibkan membayar upah kepada buruh, pada waktu yang telah ditentukan. Secara umum pekerja/buruh telah mendapat perlindungan dari pemerintah akan tetapi untuk besarnya upah yang akan diperoleh buruh/pekerja disesuaikan dengan perjanjian yang telah disepakati. Artinya pemerintah atau negara tidak ikut campur perihal besarnya upah yang akan diperoleh pekerja/buruh. Pengupahan dalam KUHPerdata pengusaha masih memiliki bergaining position yang kuat, buruh/pekerja pasrah dengan upah yang akan ditawarkan oleh pengusaha sedangkan pemerintah tidak dilibatkan perilah pengupaha.

Pada tahun 1947, di undangkannya Undang-Undang Nomor 33 tahun 1947 tentang Kecelakaan. Subtansi dari undang-undang itu dibuat untuk melindungi buruh yang mendapat kecelakaan pada saat melakukan kerja dengan majikan. Akan tetapi undang-undang Kecelakaan itupun mengatur mengenai upah. Pada saat di undangkan undang-undang kecelakaan dapat dikatakan merupakan awal mula pemerintah ikut serta pada masalah pengupahan.

Pemerintah semakin intens dalam membuat kebijakan dibidang perburuhan, diantaranya yang berkaitan dengan pengupahan. Undang-undang Nomor 80 Tahun 1957 tentang persetujuan konvensi ILO Nomor 100, mengenai pengupahan bagi laki-laki dan wanita untuk pekerja yang sama nilainya. Subtansi dari undang-undang tersebut menghapus diskriminasi antara pekerja wanita dan lelaki dalam pekerjaan sama perihal pengupahan. Maksudnya pengupahan tidak mengenal gender, laki-laki dan perempuan untuk pekerjaan yang sama upahnya harus sama (equal pay for equal work).

Selanjutnya, untuk melaksanakan ketentuan undang-undang Nomor 80 Tahun 1957 tentang persetujuan konvensi ILO Nomor 100. Disahkan Peraturan Pemerintah Nomor 8 Tahun 1981 tentang Perlindungan Buruh. Dasar disahkan PP tersebut karena sistem pengupahan pada 
saat itu tidak sesuai lagi dengan perkembangan keadaan, sehingga segala pasal yang menyangkut pengupahan dalam KUHPerdata tidak berlaku selagi telah diatur dalam PP N0 8 Tahun 1981. Pasal-Pasal tersebut antara lain Pasal 1601p, Pasal 1601q, Pasal 1601s, Pasal 1601t, Pasal 1601u, Pasal 1601v, Pasal 1602, Pasal 1602a, sampai Pasal 1602v, alinea 5 1968, alinea 3 dan 1971. Adapun Pasal dalam KUHPerdata yang masih berlaku yaitu Pasal 1602 e. Dengan tidak berlakunya lagi sebagian pasal dalam KUHPerdata mengenai pengupahan setelah di sahkannya PP tersebut dapat dikatakan kebijakan pengupahan tidak lagi bersifat hukum privat.

Pergeseran tersebut dapat dilihat melalui adanya sanksi pidana yang dinyatakan dalam PP tersebut. Acaman diantaranya apabila pengusaha melakukan diskriminasi terhadap pembayaran upah untuk buruh laki-laki dan buruh perempuan. Pengusaha yang melakukan diskriminasi tersebut akan diancam dengan pidana kurungan selama-lamanya 3 (tiga) bulan atau denda setinggi-tingginya Rp 100.000,00. Adanya ancama pidana membuktikan bahwa pengupahan telah menjadi kepentingan umum. Maksudnya dalam penentuan besaran upah tidak didasarkan atas perjanjian antara pekerja/buruh dan pemberi kerja akan tetapi pemerintah ikut andil dalam penentuan upah. Ikut andilnya pemerintah dalam hukum privat dikenal dengan istilah socialisering process. Menurut Pitaya socialisering process merupakan proses ikut campur tangannya pemerintah dalam kehidupan keperdataan untuk melindungi pihak yang lemah.

Pada tahun 1999 pemerintah menetapkan Peraturan Menteri Tenega Kerja Nomor 01 Tahun 1999 tentang Upah minimum. Campur tangan pemerintah di bidang pengupahan mengenai upah minimum, membuat pemerintah semakin jauh mengurusi rana privat dari hukum perburuhan. Sehingga dominasi hukum publik semakin kuat dalam kebijakan pengupahan terkhusus upah minimu. Pemberi kerja/pengusaha dilarang memberikan upah kepada pekerja/buruh di bawah upah minimu kecuali yang telah mendapatkan penangguhan pembayaran upah minimum dari pemerintah. Penangguhan tersebut diatur dalam ketentuan Keputusan Meteri Tenaga Kerja dan Transmigrasi RI Nomor: KEP.231/Men/2003 tentang Tata Cara Penangguhan Pelaksanaan Upah Minimum

Pada tanggal 25 Maret 2003, diundangkan Undang-Undang Ketenagakerjaan Nomor 13 Tahun 2003. Ketentuan yang mengatur pengupahan dapat dijumpai pada BAB X, bagian kedua dari pasal 88 sampai pasal 98 UUK. Hadirnya UUK semakin memperkuat dominasi pemerintah untuk mengatur kebijakan pengupahan.

Pasal 93 ayat 1 UUK menyatakan bahwa Upah tidak dibayar apabila pekerja/buruh tidak melakukan pekerjaan. Pasal Ini merupakan warisan dari KUHPerdata 1602b "Tidak ada upah 
yang harus dibayarkan untuk jangka waktu selama si buruh tidak melaksanakan pekerjaannya”. UUK dalam prakteknya masih melestarikan asas No Work, No Pay yang artinya pekerja atau buruh tidak akan mendapakan upah dalam bentuk uang atau yang lainya selama buruh/pekerja tersebut tidak melakukan pekerjaannya. Menurut penulis hal yang wajar jika pemberian upah dilandasi dengan pekerjaan yang dilakukan, karena pemberi kerja untuk dapat melangsungkan usahanya (produksinya) bergantung pada tenaga, ide dan gagasan dari pekerja atau buruh. Jika pekerja tidak melakukan pekerjaannya tetapi ingin mendapatkan bayaran yang "utuh", hal tersebut akan merugikan pihak pengusaha/pemberi kerja.

UUK mengakui adanya asas no work, no pay, akan tetapi memberikan pula pengecualian atas asas tersebut dengan tujuan untuk memberikan perlindungan kepada upah buruh/pekerja. Menurut Iman Soepomo sebagaimana dikutip oleh Lalu Husni salah satu bentuk perlindungan terhadap pekerja/buruh diberikan perlindungan terhadap penghasilan yang cukup termaksud bila pekerja/buruh tidak melakukan pekerjaan di luar kehendaknya.

Pasal 93 ayat 2 UUK yang berbunyi " ketentuan sebagaimana dimaksud dalam ayat (1) tidak berlaku dan pengusaha wajib membayar upah apabila: 1. Pekerja/buruh sakit sehingga tidak dapat melakukan pekerjaan; 2. Pekerja/buruh perempuan yang sakit pada hari pertama dan kedua masa haidnya sehingga tidak dapat melakukan pekerjaan; 3. Pekerja/buruh tidak masuk kerja karena pekerja/buruh menikah, menikahkan, mengkhitankan, membaptiskan anaknya, istri melahirkan atau keguguran kandungan, suami atau istri atau anak atau menantu atau orang tua atau mertua atau anggota; keluarga dalam satu rumah meninggal dunia; 4. Pekerja/buruh tidak melakukan pekerjaannya karena sedang menjalankan kewajiban terhadap negara; 5. Pekerja/buruh tidak dapat melakukan pekerjaannya karena menjalankan ibadah yang diperintahkan agamanya; 6 . Pekerja/buruh bersedia melakukan pekerjaan yang telah dijanjikan tetapi pengusaha tidak memperkerjakannya, baik karena kesalahan sendiri maupun halangan yang seharusnya dapat dihindari pengusaha; 7. Pekerja/buruh melaksanakan hak istirahat; 8. Pekerja/buruh melaksanakan tugas serikat pekerja/serikat buruh atas persetujuan pengusaha; dan 9. Pekerja/buruh melaksanakan tugas pendidikan dari perusahaan.

Undang-Undang Ketenagakerjaan memberikan pengecualian terhadap asas no work, no pay, sehingga buruh/pekerja masih mendapatkan upah walaupun tidak melakukan pekerjaan dengan catatan buruh/pekerja berada pada keadaan yang ditentukan UUK yaitu Pasal 93 ayat 2. Akan tetapi dalam Pasal 93 ayat 2 UUK tidak mencantumkan mogok kerja sebagai salah satu alasan pengecualian asas no work no pay.

\section{Asas No Work, No Pay Terhadap Mogok Kerja Yang Dilakukan Pekerja/Buruh}


Hubungan industrial tidak selamanya berlangsung romantis dan harmonis akan tetapi perselisihan dan perbedaan pendapat akan selalu ada. Pekerja/buruh pada posisi tawar yang lemah terkadang mendapat perlakuan sewenang-wenang dari pengusaha/pemberi kerja dengan tidak memberikan hak normatif pada pekerja/buruh. Upah yang diterima bernilai asimetris dengan produktifitas atau tenaga yang dikeluarkan. Pekerja/buruh dituntut prima dan maksimal dalam bekerja akan tetapi upah yang diberikan jauh dari kata layak atau sejahtera. Pada kondisi seperti ini banyak cara yang dilakukan pekerja/buruh diantaranya larangan untuk lembur, hanya duduk-duduk di tempat kerja, memperlambat produksi atau melakukan mogok kerja.

Mogok kerja merupakan hak normatif pekerja/buruh yang dilindungi oleh Negara. Pengakuan Pemerintah Indonesia terhadap hak mogok pekerja/buruh ini dimulai dengan diratifikasinya Konvensi ILO Nomor 98 tentang Pelaksanaan Prinsip-Prinsip Hak Berorganisasi dan Berunding Bersama melalui Undang-Undang Nomor 18 Tahun 1956. Werner Sengenberger dan Cambell Duncan sebagaimana dikutip oleh Ari Hernawan menyebutkan bahwa hak berunding kolektif menurut ILO meliputi hak berorganisasi, hak berunding dan hak mogok.

Kemudian, dimulainya era reformasi pada tahun 1998 telah memberikan pengaruh yang besar terhadap pengakuan hak-hak asasi manusia dalam segala bidang kehidupan, termasuk bidang kebebasan serikat pekerja/serikat buruh dalam menyampaikan pendapatnya. Pemerintah Indonesia kemudian meratifikasi juga Konvensi ILO Nomor 87 tentang Kebebasan Berserikat dan Perlindungan Hak untuk Berorganisasi melalui Keputusan Presiden Nomor 83 Tahun 1998 yang memberi kekebasan terhadap serikat pekerja/serikat buruh untuk menyampaikan pendapatnya. Selanjutnya, keberadaan mogok kerja semakin kokoh mendapatkan perlindungan dari Negara dengan hadirnya Undang-Undang Nomor 13 Tahun 2003 tentang Ketenagakerjaan (selanjutnya disebut UUK) Pasal 137 sampai dengan Pasal 145 dan Keputusan Menteri Tenaga Kerja dan Transmigrasi (Kepmenakertrans) No. 232 Tahun 2003 tentang Akibat Hukum Mogok Kerja yang Tidak Sah.

Berdasarkan peraturan yang mengatur mengenai mogok kerja secara umum mogok kerja dapat dikategorikan menjadi 2 (dua) yaitu mogok kerja yang tidak sah dan mogok kerja yang dilakukan secara sah. Mogok kerja yang tidak sah diatur pada Keputusan Menteri Tenaga Kerja dan Transmigrasi (Kepmenakertrans) No. 232 Tahun 2003 yaitu sebagai berikut mogok kerja tidak sah apabila dilakukan: a. Bukan akibat gagalnya perundingan; dan/atau b. Tanpa pemberitahuan kepada pengusaha dan instansi yang bertanggungjawab di bidang ketenagakerjaan; dan/atau c. Dengan pemberitahuan kurang dari 7 (tujuh) hari sebelum pelaksanaan mogok kerja; dan/atau d. Isi pemberitahuan tidak sesuai dengan ketentuan Pasal 
140 ayat (2) huruf a, b, c, dan d Undang-Undang Nomor 13 Tahun 2003 tentang Ketenagakerjaan.

Pasal 140 ayat (2) UUK mengatur bahwa pemberitahuan mogok kerja sekurangkurangnya memuat: a. Waktu (hari, tanggal, dan jam) dimulai dan diakhiri mogok kerja; b. Tempat mogok kerja; c. Alasan dan sebab-sebab mengapa harus melakukan mogok kerja; dan d. Tanda tangan ketua dan sekretaris dan/atau masing-masing ketua dan sekretaris serikat pekerja sebagai penanggung jawab mogok kerja.

Mogok kerja yang dilakukan tidak sesuai dengan prosedur yang telah ditentukan dalam undang-undang ketenagakerjaan. Maka, mogok kerja tersebut dianggap tidak sah, konsekuensinya ketika mogok kerja tidak sah dapat dikualifikasikan sebagai mangkir. Pasal 168 UUK menjelaskan bahwa pekerja yang mangkir selama 5 (lima) hari kerja atau lebih berturut-turut dan telah dipanggil oleh pengusaha 2 (dua) kali secara patut dan tertulis dapat diputuskan hubungan kerjanya karena dianggap mengundurkan diri.

Mogok kerja yang dilakukan oleh pekerja/buruh tidak sesuai dengan prosedur yang telah ditetapkan dalam UUK maupun keputusan Menteri Tenaga Kerja maka mogok kerja tersebut dinyatakan tidak sah, konsekuensinya pekerja yang melakukan mogok dinyatakan tidak bekerja sehingga tidak mendapatkan upah. Pada saat pekerja/buruh melakukan mogok kerja pada saat itu pula tidak mendapatkan upah, disamping tidak mendapatkan upah pekerja/buruh dikualifasikan mangkir.

Mogok kerja yang sah dilakukan oleh pekerja/buruh berdasarkan ketentuan UndangUndang Ketenagakerjaan. Pasal 137 UUK menyatakan bahwa mogok kerja sebagai hak dasar pekerja/buruh dan serikat pekerja/ serikat buruh dilakukan secara sah, tertib dan damai sebagai akibat gagalnya perundingan. Mogok kerja sebagai akibat gagalnya perundingan, ketentuan ini menekankan bahwa mogok hanya boleh dilakukan sebagai akibat dari dua situasi: a. Apabila telah dilakukan upaya perundingan terlebih dahulu namun gagal menjadi kesepakatan; b. Apabila pihak pengusaha menolak diajak untuk berunding. Jadi, sahnya mogok kerja harus diawali dengan perundingan terlebih dahulu, perundingan boleh dilakukan antara pekerja atau organisasi serikat pekerja dengan pemberi kerja (internal perusahaan) atau melibatkan pihak Dinas Ketenagakerjaan setempat yang bertujuan untuk mediasi problem yang terjadi.

Setelah proses perundingan namun gagal, untuk sahnya mogok kerja harus memenuhi prosedur yang telah ditetap UUK.. Pasal 140 ayat 1 UUK menyatakan " sekurang-kurangnya dalam waktu 7 (tujuh) hari kerja sebelum mogok kerja dilaksanakan, pekerja/buruh dan serikat pekerja/serikat buruh wajib memberitahukan secara tertulis kepada pengusaha dan instansi yang bertanggung jawab di bidang ketenagakerjaan setempat. Artinya sebelum melakukan 
mogok pekerja/serikat pekerja wajib membuat suatu surat yang ditujukan kepada pengusaha dan dinas ketenagakerjaan setempat. Subtansi surat tersebut memuat ketentuan pasal 140 ayat 2 yaitu: a. Waktu (hari, tanggal, dan jam) dimulai dan diakhiri mogok kerja; b. Tempat mogok kerja; c. Alasan dan sebab-sebab mengapa harus melakukan mogok kerja; dan d. Tanda tangan ketua dan sekretaris dan/atau masing-masing ketua dan sekretaris serikat pekerja/serikat buruh sebagai penanggung jawab mogok kerja.

Dinas Tenaga kerja setempat dan pengusaha yang menerima surat pemberitahuan mogok tersebut wajib memberikan tanda terima. Setelah pekerja/serikat pekerja yang akan mogok menerima tanda terima tersebut baru boleh dilakukan mogok kerja. Berdasarkan tata cara formal yang ditentukan UUK sebagai syarat sahnya mogok kerja, maka dapat dikatakan tidak ada mogok kerja yang dilakukan pekerja/buruh yang sah. UUK lebih melihat administrasi atau formalitas dari mogok kerja dibandingkan dengan melihat tujuan dan maksud pekerja/buruh melakukan mogok kerja.

Menurut Ari Hernawan, mengkritisi mogok kerja sah yang pada kenyataannya sulit terpenuhi sebagai berikut Pemogokan tidak lagi dilihat secara subtansial, apa yang menjadi sebab atau alasan mogok tetapi apakah mogok itu sudah memenuhi tata cara formal bisa dikatakan bahwa undang-undang ketenagakerjaan memang memandang mogok dalam kerangka formal belaka, legalitas hukum suatu pemogokan diutamakan dari pada subtansi karena mengutamakan formalitas apa yang menjadi subtansi mogok kerja potensial menjadi terlupakan, kondisi tersebut menjadikan negara tidak mau peduli pada apa yang menjadi subtansi pemogokan dan lebih mengurus soal tata cara dan prosedur mogok apakah sudah sesuai atau tidak sesuai dengan tata cara tersebut. Diluar prosedur tersebut mogok dianggap liar dan tidak sah dan karenanya tidak mendapat perlindungan Negara sebagai mogok sah.

Mogok kerja sah mendapat perlindungan dari Negara, bahkan pengusaha wajib memberikan upah kepada pekerja/buruh yang melakukan mogok kerja sah. Artinya bahwa mogok kerja yang sah merupakan pengecualian dari asas no work, no pay. Pekerja/buruh yang melakukan mogok kerja sah maka terhitung sedang melakukan pekerjaan. Akan tetapi, tidak semua mogok kerja sah mendapatkan pembayaran upah, hanya mogok kerja yang tuntutannya hak normatif (hak yang telah ditentukan dalam undang-undang) yang sungguh-sungguh dilanggar oleh pengusaha yang akan mendapatkan upah. Pasal 145 UUK lebih mempersempit pengecualian asas no work, no pay. Bahwa tidak semua mogok kerja akan mendapatkan upah akan tetapi mogok kerja yang tuntutannya hak normatif yang benar-benar dilanggar oleh pengusaha yang akan mendapatkan upah. 


\section{SIMPULAN}

Asas No Work, No Pay sangat erat kaitannya dengan pengupahan, karena makna dari No Work No Pay yaitu pekerja/buruh yang tidak melakukan kerja atau produksi maka pekerja/buruh tidak mendapatkan upah. Artinya pemberian upah integral dengan ide, gagasan dan tenaga yang dioptimalkan buruh/pekerja. Asas No Work, No Pay tetap dipertahankan semenjak diberlakukannya KUHPerdata sebagai peraturan yang mengatur ketenaga kerjaan sampai sebagian pasal dalam KUHPerdata tidak digunakan lagi semenjak di sahkannya undangundang nomor 13 tahun 2003 tentang ketenaga kerjaan. Akan tetapi dalam UUK asas no work, no pay terdapat pengecualian sehingga buruh masih memperoleh upah apabila, tidak bekerjanya tersebut masuh dalam kategori yang diatur dalam pasal 93 ayat 2 UUK. Walaupun dalam pasal tersebut tidak mencantumkan mogok kerja sebagai salah satu sebab pengecualian dari asas tersebut. Akan tetapi di Pasal yang lain UUK mencantumkan mogok kerja sebagai salah satu sebab pengecualiannya.

Mogok kerja sah yang dilakukan oleh pekerja/buruh mendapatkan perlindungan dari Negara, sehingga pemberi kerja diwajibkan membayarkan upah selama melakukan mogok kerja. UUK lebih rinci perilah pemberian upah kepada pekerja/buruh yang melakukan mogok kerja. Yaitu hanya mogok kerja sah dan tuntutannya hak normatif yang betul-betul dilanggar oleh pemberi kerja yang berhak mendapatkan upah.

\section{DAFTAR PUSTAKA}

Hernawan, Ari, 2013, Ketidakadilan Dalam Norma dan Praktik Mogok Kerja Di Indonesia, Udayana University Press, Bali

Hernawan Ari "Keseimbangan Hak dan Kewajiban Pekerja dan Pengusaha Dalam Mogok" Jurnal Mimbar Hukum, Fakultas Hukum Universitas Gadjah Mada Vol. 24. Oktober. 2012.

Husni Lalu, 2003, Pengantar Hukum Ketenagakerjaan, RajaGrafindo Persada, Jakarta

Koeshartono. D dan M.F. Shellyana Junaedi, 2005, Hubungan Industrial Kajian Konsep dan Permasalahan, Universitas Atma Jaya, Yogyakarta

Pitaya "Dilematika Penetapan Upah Minimum" Jurnal Mimbar Hukum, Fakultas Hukum Universitas Gadjah Mada Vol 18 Juni 2006

Saleh, Mohammaddan, Lilik Mulyadi, 2012, Seraut Wajah Pengadilan Hubungan Industrial Indonesia (Perspektif, Teoritis, Praktik, dan Permasalahan), PT Citra Aditya Bakti, Bandung,

Saprudin "Socialisering process Hukum Perburuhan dalam Aspek Kebijakan Pengupahan" Jurnal Mimbar Hukum, Fakultas Hukum Universitas Gadjah Mada Vol 24, Oktober 2012

Sumardjono, Maria S.W, 2014, Bahan Kuliah Metodologi Penelitian Ilmu Hukum, Universitas Gadjah Mada, Yogyakarta

Syafaat Rachmad, 2008, Gerakan Buruh dan Pemenuhan Hak Dasarnya: Strategi Buruh dalam Melakukan Advokasi, In-trans Publising, Malang,

Uwiyono, Aloysius 2001, Hak Mogok di Indonesia, Universitas Indonesia Fakultas Hukum Program Pasca Sarjana, Jakarta 
Undang-Undang Nomor 13 Tahun 2003 tentang Ketenagakerjaan (Lembaran Negara Republik Indonesia Tahun 2003 Nomor 39, Tambahan Lembaran Negara Republik Indonesia Nomor 4279)

Keputusan Menteri Tenaga Kerja dan Transmigrasi RI Nomor Kep 232/Men 2003 tentang Akibat Hukum Mogok Kerja Yang Tidak Sah. 